Annals of Plant and Soil Research 22(4): 390-395 (2020)

https://doi.org/10.47815/apsr.2020.10010

\title{
Management of Anthracnose of red chilli caused by Colletotrichum capsici
}

\author{
ABHA ANAND ${ }^{1}$, H.B. GUPTA ${ }^{2}$ AND H.K. CHOURASIA* \\ *Applied Microbiology and Plant Pathology Laboratory, University Department of Botany \\ T.M. Bhagalpur University, Bhagalpur-812007, Bihar, India
}

Received: August, 2020; Revised accepted: October, 2020

\begin{abstract}
Anthracnose is the common name for plant diseases characterized by very dark sunken lesions, containing spores. Colletotrichum capsici, the causal agent of red chilli anthracnose, is a major constraint in chilli production leading to huge economic losses in the country. In the present study, an attempt was made to evaluate eight chemical and botanical fungicides against C. capsici in vitro and in the field conditions at T.M. Bhagalpur University, Bhagalpur during the years 2017-2019. Results revealed that the fungicides tebuconazole, hexaconazole, trifloxystrobin, mancozeb and saponin at 0.05 and $0.10 \%$ concentrations were effective in inhibiting the mycelial growth and sporulation invitro over control, while carbendazim, neem oil, azadirachtin were least effective. When evaluated by fruit dip method for uninjured and injured inoculated fruits under laboratory condition, tebuconazole, hexaconazole and saponin significantly reduced fruit anthracnose. In protective field spray condition, hexaconazole was found most effective in reducing fruit anthranose (PEDC 83.3\%) and increasing fruit yield (225.50 $\left.\mathrm{q} \mathrm{ha}^{-1}\right)$ followed by trifloxystrobin $\left(77.5 \%, 220.25 \mathrm{qha}^{-1}\right)$, mancozeb $\left(71.6 \%, 218.10\right.$ qha $\left.^{-1}\right)$ and carbendazim $\left(68.2 \%, 214.32\right.$ qha $\left.^{-1}\right)$ as compared to control $\left(0.0 \%, 122.10\right.$ qha $^{-1}$. Neem oil (1\%) was least effective in reducing fruit anthranose (52.0\%) and yield (177.50 q ha $\left.{ }^{-1}\right)$.
\end{abstract}

Key words: Management, anthracnose, red chilli, Colletotrichum capsici

\section{INTRODUCTION}

Chilli (Capsicum annuum Linn.) is one of the major spice crops grown throughout the world and belongsto the family Solanaceae. India is the second largest exporter of chillies in the world. In India, it is cultivated commercially in summer in Bihar, Madhya Pradesh, Uttar Pradesh, Tamil Nadu, Karnataka, Andhra Pradesh and Rajasthan.It is not only used in many cuisines but also found to have many medicinal properties. In addition, chilli, can reduce the risk of cancer by preventing carcinogens from binding to DNA and reduce calorie intake by increasing thermogenesis (Saxena et al., 2014). Many researchers have reported that Colletotrichum causes anthracnose disease and post-harvest decay on a wide range of tropical, subtropical and temperate fruits, crops and ornamental plants (Sharma et al., 2011, Damm et al., 2012, Saxena et al., 2016). The chilli anthracnose disease drastically reduces the qualityand yield of chilli fruits resulting in low returns to farmers. In India, it causes severe damage to fruits in the field as well as in storage and takes heavy toll upto 84 per cent (Saxena et al., 2014).Typical anthracnose symptoms on red chilli fruits include sunken necrotic tissues, with concentric rings of acervuli andfused lesions. Conidial masses may occur under severe conditions. Several species of Colletotrichum etiologicallyassociated with anthracnose diseases in chilli include $C$. acutatum, C. coccodes, C. dematium and C. gloeosporioides in India (Sharma et al., 2011). According to Kim et al. (2008), different species infect chilli plants at different growthstages. Colletotrichum capsici is found to be prevalent in red chilli fruits, whereas $C$. acutatum and $C$. gloeosporioides cause infections both in young and mature chilli fruits (Than et al., 2008, Rashid et al., 2015). Among these species, $C$. gloeosporioides and $C$. acutatum are themost destructive and widely distributed (Sarath Babu et al., 2011).Plant protections through chemicals contribute significantly to reduce losses due to diseases and thereby increase agricultural production. However, chemicals pollute and induce resistance amongst pathogen. Hence, there is an urgent need to look for an alternative safer means for managing plant diseases. Use of botanicals for prevention of plant diseases has been recorded in ancient Indian agriculture. Several botanicals viz., leaves and oil of neem (Azadirachta indica A. Juss.) leaves of garlic (Allium sativum L.), leaves and fruits of datura (Datura stramonium L.), seeds of babool (Acacia nilotica(L.) Delite.)and fruits of brhati (Solanum

${ }^{*}$ Correspondence E-mail: hkchourasia96@gmail.com ${ }^{\top}$ Government P.G. College, Rajgarh (Biaora), M.P.. ${ }^{2}$ Institute for Excellence in Higher Education, Bhopal, M.P. 
indicum L.) have antimicrobial activities against some plant pathogens (Kumar and Yadav, 2007, Meena et al., 2007, Menaria et al., 2012). Hence, this study was conducted to evaluate some commonly available systemic and nonsystemic chemical fungicides, and neem-based fungicides against the disease under laboratory and field conditions to develop a cost-effective management method for anthracnose of red chilli.

\section{MATERIALS AND METHODS}

\section{In vitro evaluation of fungicides against Colletotrichum capsici}

Eight fungicides viz., mancozeb, carbendazim, tebuconazole, hexaconazole, trifloxystrobin, saponin, neem oil (Nimbidin, 50 ppm Azadirachtin) and Achook (Azadirachtin $1500 \mathrm{ppm}$ ) were tested using the poisoned-food technique (Nene and Thapliyal, 1979) at two concentrations 0.05 and $0.10 \%$ a.i. along with a control where no fungicide was added to the PDA medium. The data on fungal growth diam $(\mathrm{mm})$ was recorded 7 days after incubation at $25 \pm 1^{\circ} \mathrm{C}$ when control plates were fully covered with mycelium. Per cent inhibition in each treatment over control was calculated.

\section{Datached fruit dip treatment technique}

Surface sterilized healthy fruits of red chilli of nearly equal size were used. In uninjured inoculation treatment, the fresh fruits were inoculated with spore suspension $\left(5 \times 10^{6}\right.$ spores $\mathrm{ml}^{-1}$ ) for $24 \mathrm{hr}$ at $25 \pm 1^{\circ} \mathrm{C}$ and were then dipped in the test fungicides for $5 \mathrm{~min}$, while in the injured inoculation treatment, the fruits were first pin pricked and inoculated with spore suspension $\left(5 \times 10^{6}\right.$ spores $\left.\mathrm{ml}^{-1}\right)$ then treated with the test fungicides after $24 \mathrm{hr}$ of incuabation at $25 \pm 1^{\circ} \mathrm{C}$. Fruits dipped in sterilized distilled water served as control. The treatments were replicated thrice having 3 fruits in each replication. To maintain high humidity the inoculated treated fruits with a piece of moistened cotton were kept in sterilized polythene bags and were incubated at $25 \pm 1^{\circ} \mathrm{C}$. Fruit anthracnose development was recorded on $8^{\text {th }}$ day of inoculation following a $0-5$ rating scale where $0=$ no sysmptom; $1=1-20 \%$ fruit area affected, 2=21-40\% fruit area affected, 3=41$60 \%$ fruit area affected, $4=61-80 \%$ fruit area affected and $5=$ more than $80 \%$ fruit area affected. The percent disease index (PDI) as well as per cent efficiency of disease control (PEDC) were calculated as per the formula of Pathak et al. (1996).

\section{Fungicides evaluation under field condition}

Five effective fungicides that were found effective in in vitro evaluation were used in this study. These weremancozeb $(0.20 \%)$, carbendazim $(0.10 \%)$, trifloxystrobin $(0.10 \%)$, neem oil (1.0\%) and hexaconazole $(0.05 \%)$. Though tebuconazole was equally effective in in vitro studies but it could not be evaluated in field condition as it is still under trial for recommendation. Each treatment consisted of three replications with a $3 \times 2 \mathrm{~m}$ plot (20 plants plot $^{-1}$ ). Sixty-day-old chilli plants at flowering and fruiting stages were inoculated by the pathogen spore suspension $\left(5 \times 10^{6}\right.$ spores $\left.\mathrm{ml}^{-1}\right)$ and the test fungicides were sprayed after $24 \mathrm{hr}$. After 15 days of spray application, 10 plants were randomly selected from each plot to record disease incidence. Yield was recorded on the basis of numbers and weight of fruits per plant. The data were statistically analyzed to determine significant treatment differences. In vitro evaluation of fungicides against $C$. capsici was conducted in the Applied Microbiology and Plant Pathology Laboratory of T.M. Bhagalpur University, Bhagalpur and field experiment was laid out in a randomized block design at the University farm during 2017-2019.

\section{RESULTS AND DISCUSSION}

\section{Efficacy of fungicides invitro}

The results (Table 1) clearly indicated that almost all the fungicides tested were significantly superior to the control in inhibiting the growth of $C$. capsici. Out of 8 fungicides, two, viz., tebuconazole (100\%) and hexaconazole $(100 \%)$ proved to be most effective as they completely inhibited the growth of the fungus at $0.05 \%$ and $0.10 \%$ concentrations in bioassay test. The remaining fungitoxicants, although, inhibited the growth of fungus to varying degree but failed to exhibit complete inhibition and therefore, these were considered to be partially effective. Among the partially effective chemicals, saponin (83.8\%) and trifloxystrobin 
$(80.2 \%)$ gave maximum inhibition of fungal growth and were significantly superior to remaining ones. Mancozeb proved to be the next best followed by carbendazim and neem oil as they inhibited $76.7,65.7$ and $50.1 \%$ growth of fungus, respectively. The least inhibition (41.9\%) of growth was recorded with azadirachtin. Tebuconazole and hexaconazole completely inhibited sporulation of $C$. capsici, while trifloxystrobin and saponin showed poor antisporulation activity (Table 1 ).

Table 1: In vitro evaluation of fungicides against mycelial growth and sporulation of $C$. capsici

\begin{tabular}{|c|c|c|c|c|c|}
\hline \multirow[t]{2}{*}{ Fungicide } & \multicolumn{2}{|c|}{$\begin{array}{l}\text { Mycelial growth }(\mathrm{mm})^{*} \text { at } \\
\text { conc. }(\%)\end{array}$} & \multicolumn{2}{|c|}{$\begin{array}{l}\text { Inhibition over control (\%) } \\
\text { Inhibition over control (\%) }\end{array}$} & \multirow[t]{2}{*}{ Sporulation** } \\
\hline & 0.05 & 0.10 & 0.05 & 0.10 & \\
\hline Mancozeb & 40.3 & 25.0 & 59.5 & 76.7 & ++ \\
\hline Carbendazim & 56.0 & 33.9 & 40.9 & 65.7 & ++ \\
\hline Tebuconazole & 0.0 & 0.0 & 100 & 100 & - \\
\hline Haxaconazole & 0.0 & 0.0 & 100 & 100 & - \\
\hline Trifloxystrobin & 49.0 & 20.9 & 48.9 & 80.2 & + \\
\hline Saponin & 24.2 & 17.8 & 76.5 & 83.8 & + \\
\hline Neem oil & 66.0 & 47.9 & 30.0 & 50.1 & +++ \\
\hline Azadirachtin & 88.1 & 56.0 & 5.2 & 41.9 & +++ \\
\hline Control & 92.0 & 92.0 & 0.0 & 0.0 & +++ \\
\hline$C D(P<5 \%)$ & 3.1 & 1.7 & & & \\
\hline
\end{tabular}

${ }^{\star}$ Average of three replications; ${ }^{* *}+++=$ Abundant, $++=$ Good, $+=$ poor, $-=$ Nil

Efficacy of fungicides by detached fruit dips method

The results on the effect of eight fungicides on uninjured inoculation experiments revealed that all the fungitoxicants helped in reducing development of anthracnose symptom on detached chilli fruits compared to untreated control (Table 2). Significant decrease in fruit anthracnose was obtained in case of tebuconazole $(92.7 \%)$ followed by hexaconazole $(88.5 \%)$, trifloxystrobin $(78.0 \%)$, mancozeb $(65.0 \%)$ and carbendazim $(62.9 \%)$ at $0.05 \%$ concentration. Although, per cent efficacy of disease control was moderately lowered in case of other fungicide treatments viz., saponin $(61.0 \%)$, neem oil (51.1\%) and azadirachtin (46.1\%), but they did not differ significantly from the untreated check considering the results of both the years (2017-18 and 2018-19). Tebuconazole was capable of more than $90 \%$ checking the disease development due to $C$. capsici infestation. At $0.10 \%$ concentration of fungicides, maximum disease control was observed in tebuconazole (96.0\%), hexaconazole $(93.5 \%)$, trifloxystrobin $(87.2 \%)$, followed by mancozeb $(77.0 \%)$ and saponin (70.1\%).

Table 2: Effect of fungicides on uninjured inoculated fruit of red chilli

\begin{tabular}{|c|c|c|c|c|}
\hline \multirow{2}{*}{ Fungicide } & \multicolumn{2}{|c|}{ Fungicide conc. (0.05\%) } & \multicolumn{2}{c|}{ Fungicide conc. (0.10\%) } \\
\cline { 2 - 5 } & \multicolumn{1}{|c|}{ PDI $^{*}$} & PEDC $^{*}$ & PDI $^{*}$ & \multicolumn{1}{c|}{ PEDC $^{*}$} \\
Mancozeb & $35.2(36.9)^{\star *}$ & $65.0(54.8)$ & $22.8(29.0)$ & $77.0(62.2)$ \\
Carbendazim & $37.0(38.1)$ & $62.9(53.0)$ & $27.9(32.0)$ & $72.6(59.0)$ \\
Tebuconazole & $9.2(17.9)$ & $92.7(74.5)$ & $7.0(15.3)$ & $96.0(77.1)$ \\
Haxaconazole & $12.7(22.0)$ & $88.5(69.6)$ & $9.0(18.5)$ & $93.5(74.0)$ \\
Trifloxystrobin & $22.2(29.1)$ & $78.0(62.9)$ & $14.7(22.9)$ & $87.2(69.2)$ \\
Saponin & $39.0(39.3)$ & $61.0(52.1)$ & $30.2(34.0)$ & $70.1(57.3)$ \\
Neem oil & $48.1(44.7)$ & $51.1(46.0)$ & $15.1(39.5)$ & $61.0(52.1)$ \\
Azadirachtin & $59.1(47.2)$ & $46.1(43.2)$ & $44.7(42.8)$ & $54.1(47.9)$ \\
Control & $95.0(76.1)$ & $1.9(11.8)$ & $93.0(74.9)$ & $1.8(11.7)$ \\
CD (P<5\%) & 4.82 & 4.78 & 4.10 & 3.15 \\
\hline
\end{tabular}


Per cent Disease Index (PDI)=[Sum of individual ratings)/(number of fruits assessed $x$ maximum rating)] $x$ 100. Per cent Efficacy of Disease Control (PEDC) $=[($ PDI in control-PDI in treatment) / (PDI in control)] $\times 100$. The effect of fungicides on injured inoculated fruits of chilli is presented in Table 3.All the fungicides were found significantly effective in reducing the fruit anthracnose as compared to control. The maximum disease control was noticed in tebuconazole (92.5, 95.2\%), hexaconazole (87.0, 93.5\%), and trifloxystrobin (75.1, 86.0\%) at 0.05 and $0.10 \%$ concentrations, respectively. While moderate disease control was noticed in mancozeb $(62.1,70.9 \%)$, saponin $(59.2,69.0 \%)$ and carbendazim $(52.0,63.9 \%)$. The least per cent efficacy of disease control at fungicidal concentrations of 0.05 and $0.10 \%$ was recorded with neem oil $(48.2,57.1 \%)$ and azadirachtin $(40.2,44.5 \%)$.

Table 3: Effect of fungicides on injured inoculated fruits of red chilli

\begin{tabular}{|c|c|c|c|c|}
\hline \multirow{2}{*}{ Fungicide } & \multicolumn{2}{|c|}{ Fungicide conc. $(0.05 \%)$} & \multicolumn{2}{c|}{ Fungicide conc. $(0.10 \%)$} \\
\cline { 2 - 5 } & PDI $^{*}$ & PEDC $^{*}$ & PDI $^{*}$ & PEDC $^{*}$ \\
Mancozeb & $37.8(38.8)^{* *}$ & $62.1(52.1)$ & $30.1(33.9)$ & $70.9(58.1)$ \\
Carbendazim & $45.9(43.2)$ & $52.0(46.9)$ & $36.5(38.0)$ & $63.9(54.0)$ \\
Tebuconazole & $10.5(18.8)$ & $92.5(73.5)$ & $8.0(15.9)$ & $95.2(76.3)$ \\
Haxaconazole & $15.0(22.3)$ & $87.0(69.6)$ & $8.9(17.2)$ & $93.5(75.6)$ \\
Trifloxystrobin & $25.9(31.2)$ & $75.1(60.4)$ & $16.0(23.9)$ & $86.0(68.2)$ \\
Saponin & $40.0(39.8)$ & $59.2(51.3)$ & $32.1(35.0)$ & $69.0(56.8)$ \\
Neem oil & $50.2(45.9)$ & $48.2(44.9)$ & $43.0(41.2)$ & $57.1(50.2)$ \\
Azadirachtin & $57.1(50.0)$ & $40.2(40.0)$ & $54.1(48.1)$ & $44.5(42.2)$ \\
Control & $92.2(74.0)$ & $0.0(0.0)$ & $94.0(75.3)$ & $0.0(0.0)$ \\
CD $(\mathrm{P}<5 \%)$ & 4.85 & 7.95 & 4.15 & 4.25 \\
& & & &
\end{tabular}

\section{Efficacy of fungicides under field condition}

All the treatments were significantly effective in reducing fruit anthracnose severity and increasing fruit yield compared to control (Table 4). Hexaconazole was found highly effective in reducing fruit anthracnose (PEDC $83.3 \%)$ and increased fruit yield (225.50 q ha-1) followed by trifloxystrobin $\left(77.5 \%, 220.25 \mathrm{q} \mathrm{ha}^{-1}\right)$, mancozeb $\left(71.6 \%, \quad 218.10 \mathrm{q} \mathrm{ha}^{-1}\right)$ and carbendazime $\left(68.2 \%, \quad 214.32 \quad \mathrm{q} \mathrm{ha}^{-1}\right)$, respectively compared to control $(0.0 \%, 122.10$ $\left.\mathrm{q} \mathrm{ha}^{-1}\right)$. Hexaconazole was at par with trifloxystrobin in relation to fruit yield. The effect of neem oil at $1 \%$ concentration was found less effective on the incidence of fruit anthracnose (PEDC 52.0\%) and fruit yield at harvest (177.50 $\mathrm{q}$ ha $\left.^{-1}\right)$.

Table 4: Effect of fungicides on fruit anthracnose incidence and fruit yield of red chilli

\begin{tabular}{|c|c|c|c|c|}
\hline Treatment & Concentration (\%) & PDI $^{*}$ & PEDC $^{*}$ & ${\text { Fruit yield }\left(\mathrm{q} \mathrm{ha}^{-1}\right)}^{* *}$ \\
Mancozeb & 0.20 & $28.8(33.0)^{* *}$ & $71.6(58.4)$ & 218.10 \\
Carbendazim & 0.10 & $31.3(34.8)$ & $68.2(56.3)$ & 214.32 \\
Haxaconazole & 0.05 & $18.0(25.1)$ & $83.3(66.2)$ & 225.50 \\
Trifloxystrobin & 0.10 & $23.1(29.2)$ & $77.5(62.1)$ & 220.25 \\
Neem oil & 1.00 & $45.9(43.2)$ & $52.0(47.0)$ & 177.50 \\
Control & - & $90.9(72.4)$ & $0.0(0.0)$ & 122.10 \\
CD $(\mathrm{P}<5 \%)$ & 2.40 & 2.65 & 7.45 & 12.75 \\
\hline
\end{tabular}

${ }^{*}$ Average of three replication; ${ }^{* *}$ Figures in parentheses are angular transformed values

The present findings corroborate with the earlier reports (Srinivas et al., 2006, Kumar and Yadav, 2007) on Colletotrichum spp. infecting betelvine and bell pepper. They reported that the extract of Azadirachta indica was effective in inhibiting the conidial germination of $C$. gloeosporioides and $C$. capsici. The efficacy of tebuconazole and hexaconazole against red chilli anthracnose pathogen (Colletotrichum capsici) has not studied before but they are known to inhibit the growth of Curvularia lunata under laboratory condition (Menaria et al., 2012) which corroborate the result of present findings. Jadon (2009) reported that carbendazim at 
$0.05 \%$ wasalso effective against blight and fruit rot of bell peppercaused by $D$. bicolor. Sharma et al. (2004) tested different fungicides to control die back and anthracnose of chilli and found that bavistin, carbendazim and mancozeb were highly effective in inhibiting growth of the pathogen. Similar observations were recorded by Singh and Vishunavat (2010). However, no other information isavailable on $C$. capsici fruit anthracnose of red chilli and itsmanagement. The results revealed that hexaconazole was the most effective, followed by trifloxystrobin and mancozeb.

Ramdial et al. (2016, 2017) while conducting in vitro bioassay experiments on fungicidal sensitivity among isolates of Colletotrichum truncatum and Fusarium incarnatum-equiseti species complex infecting bell pepper in Trinidad, West Indies found that the development of fungicide resistance in a given fungal population depends on a number ofinteracting factors including, (i) the fitness advantage offered to resistant mutants, (ii) the population size, reproductive rate and history of resistance of the target pathogen, (iii) repetitive and sustained fungicide use especially singlesite inhibitors, (iv) no integration with other complementary non-chemical control methods, (v) exceeding the dose rate and timing of

\section{REFERENCES}

Damm, U., Cannon, P.F., Woundenberg, J.H.C., Johnston, P.R., Weir, B.S., Tan, Y.P., Shivas, R.G. and Crous, P.W. (2012) The Colletotrichum boninense species complex. Studies in Mycology 73:1-36.

Jadon, K.S. (2009) Patho- Physiological investigations on blight of bell pepper [Capsicum annuum var grossum (L) Sendt.] caused by $D$. bicolor (Mitra) Subram. \& Jain.PhD (Ag.) thesis, MPUAT, Udaipur.

Kim, J.T., Park, S, Y., Choi, W., Lee, Y.H. and Kim. H.T. (2008) Characterization of Colletotrichum isolates causing anthracnose of pepper in Korea. Plant Pathology Journal 24:17-23.

Kumar, S. and Yadav, B.P. (2007) Efficacy of fungicides and phytoextract on Colletotrichum spp. Journal of Mycology and Plant Pathology 37:363-364. application, (vi) use of chemicals as an eradicant rather than preventative application, and (vii) cross-resistance among single-site inhibitors as is the case with benzimidazoles.

A critical appraisal of field experiments revealed that there was an effective control of anthracnose of chilli fruits when known concentration of mancozeb $(0.20 \%)$, carbendazim $(0.10 \%)$, hexaconazole $(0.05 \%)$, trifloxystrobin $(0.10 \%)$ and neem oil (1\%) were sprayed after $24 \mathrm{hr}$ inoculation of plants at flowering and fruiting stages with spore suspension of $C$. capsici. Hexaconazole, trifloxystrobin, carbendazim and mancozeb gave $83.3,77.5,71.6$ and $68.2 \%$ control of anthracnose disease of chilli, respectively and subsequently these fungicides increased almost double fruit yield as compared to control. Similar to our results Singh (2007) had also suggested that a single drenching of carbendazim $(0.10 \%)$ and mancozeb $(0.25 \%)$ consistently reduced the number of wilted plants of chilli and increased marketable yields significantly. In the present study, the ested botanicals were less effective than the chemical fungicides, but more diverse types of botanicals and resident biocontrol agents need to be evaluated for developing ecofriendly and sustainable management practice for this malady.

Meena, A.K., Mali, B.L and Choudhary, S.L. (2007) Evaluation of partially purified plant products and antibacterial chemicals preparation against bacterial pathogens. Journal of Mycology and Plant Pathology 37: 365-368.

Menaria, D., Rawal, P., Mathur, K. and Saharan, V. (2012) Management of fruit rot (Curvularia lunata) of bell pepper. Journal of Mycology and Pant Pathology 42:317320.

Nene, Y.L. and Thapliyal, P.N. (1979) Fungicides in plant disease control. Oxford \& IBH Pub Co., New Delhi. 531$534 \mathrm{pp}$.

Pathak, V.N; Khatri, M.K. and Pathak, M. (1996) Fundamentals of plant pathology.AgroBotanical Publishers, Bikaner (India) 85$108 \mathrm{pp}$.

Ramdial, H., Abreu, K.D. and Rampersad, S.N. (2017) Fungicidal sensitivity among 
isolates of Colletotrichum truncatum and Fusarium incarnatum - equiseti species complex infecting bell pepper in Trinidad. Plant Pathology Journal 33: 118-124.

Ramdial, H., Hosein, F.N. and Rampersad, S.N. (2016) Detection and molecular characterization of benzimidazole resistance among Colletotrichum truncatum isolates infecting bell pepper in Trinidad. Plant Disease 100: 1146-1152.

Rashid, M.M., Kabir, M.D.H., Hossain, M.D.M., Bhuiyan, M.D.R. and Khan, M.A.I. (2015) Eco-friendly management of chilli anthracnose (Colletotrichum capsicl). International Journal of Plant Pathology 6:1-11.

Sarath Babu, B., Pandravada, S., Prasada Rao, R., Anitha. K., Chakrabarty, S. and Varaprasas, K. (2011) Global sources of pepper genetic resources against arthropods, nematodes and pathogens. Crop Protection 4:389-400.

Sexena, A., Raghuwanshi, R., Gupta, V.K. and Singh, H.B. (2016) Chilli anthracnose: The epidemiology and management. Front Microbiology 7: 15-27.

Sexena, A., Reghuwanshi, R. and Singh, H.B. (2014) Molecular, phenotypic and pathogenic variability in Colletotrichum isolatesof subtropical region in North
Eastern India, causing fruit rot of chillies. Journal of Applied Microbiology 117: 1422-1434.

Sharma, P.N., Katoch. A., Sharma, P., Sharma, S.K. and Sharma, O.P. (2011) First Report on Association of Colletotrichum coccodes with Chili Anthracnose in India. Plant Disease 95:1584.

Singh, D. (2007) Role of fungicides and biocontrol agents in the management of Fusarial wilt of chilli. Journal of Mycology Plant Pathology 37: 361-362.

Singh, K, and Vishunavat, K. (2010) Compatibility of bioagents with fungicides against anthracnose of chilli. Journal of Mycology P1ant Pathology 40: 309-310.

Srinivas, C., Niranjan, S.R., Kumar, L.P., Nayaka, S.C. and Shetty, H.S. (2006) Effect of fungicides and bioagents against Colletotrichum capsici on seed quality of chilli. Indian Phytopathology 59: 62-67.

Than, P.P., Jeewon, R., Hyde, K.D., Pongsupasamit, S., Mongkolporn, O. and Taylor P.W.J. (2008) Characterization and pathogenicity of Colletotrichum species associated with anthracnose on chilli (Capsicum spp) in Thailand. Plant Pathology 57:562-572. 